\title{
Kinetic Analysis of Net Nitrogen Mineralization in Soil ${ }^{1}$
}

\author{
N. G. Juma, E. A. Paul, AND B. Mary ${ }^{2}$
}

\begin{abstract}
Studies were conducted to determine the most suitable mathematical equation and the most appropriate method for calculating the values of the parameters of the equation describing the net $\mathbf{N}$ mineralization in soil. The cumulative net $\mathbf{N}$ mineralized in two treatments of a ${ }^{15} \mathrm{~N}$ labeled soil and five unlabeled Saskatchewan soils showed curvilinear trends that could be fitted to either hyperbolic or first order equations. The kinetic parameters of the hyperbolic equation, ${ }^{15} \mathrm{~N}_{0}^{\mathrm{H}}$ (potentially mineralizable $\mathrm{N}$ ) and $T_{\mathrm{c}}$ (time required for $1 / 2 \mathrm{~N}_{0}^{\mathrm{H}}$ to mineralize) determined by nonlinear least squares (NLLS) yielded the best fit to the data for the labeled soil and had the lowest RMS error. Linear regression $(1 / N$ vs $1 / t)$ yielded ${ }^{15} \mathrm{~N}_{0}^{\mathrm{H}}$ and $T_{c}$ values which were markedly different than those obtained with the $N$ vs. $N / t$ and $t / N$ vs. $t$ transformations or those obtained with the NLLS method when all the data were considered. The double reciprocal plot gave undue weight to the initial data points. The ${ }^{15} \mathrm{~N}_{0}^{\mathrm{H}}$ estimated by NLLS method accounted for 62 and $72 \%$ of the total organic ${ }^{15} \mathrm{~N}$ remaining in the two treatments of Weirdale loam soil. The $\mathbf{N}_{0}^{H}$ for Saskatchewan soils ranged from 51 to $429 \mu \mathrm{g} \mathrm{N} \mathrm{g}^{-1}$ soil, while the $T_{\mathrm{c}}$ ranged from 7.3 to 45.8 weeks. The ${ }^{15} \mathbf{N}_{0}^{\mathrm{F}}$ values obtained with the first order equation using NLLS method accounted for 39 to $44 \%$ of the total organic ${ }^{15} \mathrm{~N}$ remaining in soil. The $N_{0}^{F}$ values for Saskatchewan soils ranged from 35 to 255

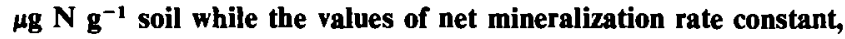
$k$, ranged from 0.036 to 0.164 weeks ${ }^{-1}$. Both equations accurately predicted the amount of net $\mathbf{N}$ mineralized over 14 weeks incubation. However, the estimates of potentially mineralizable $\mathbf{N}$ and mineralizable $\mathbf{N}$ half-life were dependent upon the model used.
\end{abstract}

Additional Index Words: ${ }^{15} \mathbf{N}_{0}$ nitrogen mineralization potential, $\mathbf{N}_{\text {o, }}$ soil $\mathbf{N}$ supplying capacity, organic $\mathbf{N}$.

Juma, N. G., E. A. Paul, and B. Mary. 1984. Kinetic analysis of net nitrogen mineralization in soil. Soil Sci. Soc. Am. J. 48:753-757.

$\mathrm{T}$ HE AMOUNT of $\mathrm{NO}_{3}^{-}-\mathrm{N}$ accumulated over extended aerobic incubation periods represents net $\mathrm{N}$ mineralization. This has been found to be a most useful measurement for determining the effect of environmental and soil variables such as temperature (Campbell et al., 1981) and texture, moisture and organic matter (Herlihy, 1979) controlling the cumulative $\mathbf{N}$ mineralized. A number of mathematical relationships can be used to describe the data obtained when $\mathrm{NO}_{3}^{-}-\mathrm{N}$ accumulation is analyzed as a function of time of incubation. Generally curvilinear relationships between the amount of $\mathrm{N}$ mineralized and the time of incubation have been found to occur (Stanford and Smith, 1972; Mary and Remy, 1979; Molina et al., 1980). These are commonly described by either hyperbolic or first-order equations. The hyperbolic equation as applied to $\mathrm{N}$ mineralization is:

$$
\mathrm{N}=\mathrm{N}_{0}^{\mathrm{H}} \cdot t /\left(b \mathrm{~N}_{0}^{\mathrm{H}}+t\right)
$$

\footnotetext{
1 Joint contribution from Univ. of Saskatchewan (Saskatchewan Inst. of Pedology Paper \# R358) and Univ. of Alberta (Alberta Inst. of Pedology publication \#T-84-1). Received 28 Jan. 1983. Approved 3 Feb. 1984.

2 Assistant Professor, Univ. of Alberta, Dep. of Soil Science, Edmonton, Alberta, Canada T6G 2E3; Professor, Univ. of California, Dep. of Plant and Soil Biology, Berkeley, CA 94720, U.S.A.; Research Scientist, I.N.R.A. Laon, France; respectively.
}

where $\mathrm{N}$ is the cumulative $\mathrm{N}$ mineralized $(\mu \mathrm{g} \mathrm{N} \mathrm{g}$ soil), $\mathrm{N}_{0}^{\mathrm{H}}$ is defined as the potentially mineralizable $\mathrm{N}$ pool, $t$ is time (weeks), and $b$ is a constant [weeks . $\left(\mu \mathrm{g} \mathrm{N} \mathrm{g}{ }^{-1}\right.$ soil) ${ }^{-1}$. Many workers have used a linear transformation of the above equation to obtain a first approximation of the size of $\mathrm{N}_{0}$ in soils (Stanford and Smith, 1972; Oyanedel and Rodriguez, 1977; Sinha et al., 1977; Herlihy, 1979; Campbell et al., 1981).

The first order equation describing net $\mathrm{N}$ mineralization is:

$$
\mathrm{N}=\mathrm{N}_{0}^{\mathrm{F}}[1-\exp (-k t)]
$$

where $\mathrm{N}$ is the cumulative net $\mathrm{N}$ mineralized up to time $t, k$ is the invariant rate constant (weeks ${ }^{-1}$ ) and $\mathrm{N}_{0}^{\mathrm{F}}$ is defined as the potentially mineralizable $\mathrm{N}$ pool at $t=0$. The values of $\mathrm{N}_{0}^{\mathrm{F}}$ and $k$ obtained by nonlinear least squares (NLLS) regression (Mary and Remy, 1979; Smith et al., 1980) are more precise and less ambiguous than those obtained using the double reciprocal plot of the hyperbolic equation to obtain an initial value of $\mathrm{N}_{0}$, followed by iterative plotting of $\mathrm{N}_{0}$ on a first order basis (Stanford and Smith, 1972).

The use of ${ }^{15} \mathrm{~N}$ to label an active pool of $\mathrm{N}$ makes it possible to better delineate the concept of $\mathrm{N}_{0}$ and to compare the different approaches used to describe the net $\mathrm{N}$ mineralization of soils. The objectives of this investigation were to describe net $\mathrm{N}$ mineralization using the hyperbolic and first-order equations and to compare the different approaches to describe the net $\mathrm{N}$ mineralization in soils that had both labeled and unlabeled active $\mathrm{N}$ pools.

\section{MATERIALS AND METHODS}

Soils

The soils used in this study represent the 0 - to $15-\mathrm{cm}$ layer of well drained Dark Gray, Black and Dark Brown Chernozemic soils of Saskatchewan. They had neutral $\mathrm{pH}$ and included a fourfold range of organic $\mathrm{N}$ levels (Table 1).

The Weirdale loam soil samples designated as $\mathrm{NH}_{4} \mathrm{OH}$ and $\mathrm{NH}_{4} \mathrm{OH}+$ ATC were enriched in ${ }^{15} \mathrm{~N}$ during a field experiment conducted to determine the fate of fertilizer ${ }^{15} \mathrm{~N}$ in the presence and absence of a nitrification inhibitor [4amino-1,2,4-triazole (ATC)] (Juma and Paul, 1983). The Indian Head clay soils were obtained from two long-term rotations: Rotation C was a 3-yr fallow, wheat (Triticum aes-

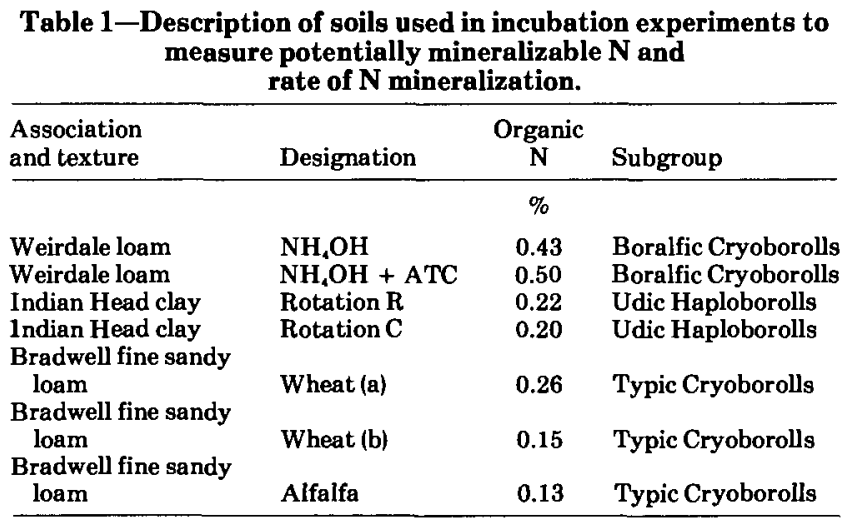


tivum L.), wheat rotation. Rotation $\mathrm{R}$ had a complex 9 year sequence- fallow, wheat, oats (Avena sativa $\mathrm{L}$.) underseeded to legume-alfalfa (Medicago sativa L.) mixture, hay, hay, hay, plus $27 \mathrm{Mg}$ of barnyard manure and partial fallow, wheat and oats (Towill, 1980). The rotations were started in 1912 and the soils were sampled in 1978.

The Bradwell fine sandy loam [designated as wheat (a)] was obtained from Goodale Farm after harvesting a wheat crop. The other Bradwell fine sandy loam soils were sampled after harvesting a wheat crop that had been grown on levelled land at Outlook, Saskatchewan. One of the fields was in a wheat fallow rotation [designated as wheat (b)] while the other was broken from 5 years of alfalfa in the previous fall.

\section{Experimental Techniques}

A leaching-incubation experiment (Stanford and Smith, 1972) was set up in triplicate with the Weirdale loam, Indian Head clay, and Bradwell fine sandy loam from Goodale to measure the net $\mathrm{N}$ mineralized during a 12- to 18-week incubation. The soils were leached at 1-, 2-, or 3-week intervals, maintained at $34 \mathrm{kPa}$ soil pore moisture tension and incubated at $28 \pm 1^{\circ} \mathrm{C}$. Two $50-\mathrm{mL}$ aliquots from the leachates were analyzed for mineral $\mathrm{N}$. The Bradwell fine sandy loam soils from Outlook were incubated in 15 - $\mathrm{L}$ plastic pails at $28 \pm 1{ }^{\circ} \mathrm{C}$ and were subsampled every 2 or 3 weeks. They were not leached as the other soils. Mineral $N$ was measured by steam distilling the $2 M \mathrm{KCl}$ extracts (1:5 soil/solution) and titrating with standard sulfuric acid (Bremner, 1965). The data reported are averages of six analyses. The coefficient of variation over all sampling times ranged between 4 and $10 \%$. The atom $\%{ }^{15} \mathrm{~N}$ abundance of mineral $\mathrm{N}$ leached from the enriched soil was measured on a Micromass 602E mass spectrometer.

\section{Calculations}

The constant $b$ in the hyperbolic equation [1] can be written as:

$$
b=T_{c} / \mathrm{N}_{0}^{\mathrm{H}}
$$

where $T_{c}$ is the time required for $1 / 2 \mathrm{~N}_{0}^{\mathrm{H}}$ to mineralize (weeks) yielding

$$
\mathrm{N}=\mathrm{N}_{0}^{\mathrm{H}} \cdot t /\left(T_{c}+t\right) .
$$

The derivative-free nonlinear least squares (NLLS) regression program described by Ralston (1983) was used to determine the parameter estimates of the hyperbolic [Eq. 4] and first order [Eq. 2] equations using the net $\mathrm{N}$ mineralization data.

Parameter estimations for three linear transformations of the hyperbolic equation were compared with those obtained with the NLLS method. Goodness of fit for the transformed data was assessed by the $R^{2}$ statistic. In addition, the ${ }^{15} \hat{N}_{0}$ and $\hat{T}_{c}$ obtained with linear transformation were used to generate the net $\mathrm{N}$ mineralization curve from which the root mean square (RMS) error was calculated. It was only possible to calculate the standard error of parameter estimates for $\mathrm{N}$ vs. $\mathrm{N} / t$ transformation because the slope and the intercept correspond to $T_{c}$ and $\mathrm{N}_{0}^{\mathrm{H}}$, respectively. In the other transformations either the slope or the intercept was made up of two terms: $\mathrm{N}_{0}^{\mathrm{H}}$ and $T_{c}$. Linear regression yielded the standard error of the combined term making it difficult to estimate the variance due to each parameter. The standard error of parameter estimates were calculated directly in the NLLS method.

\section{RESULTS AND DISCUSSION}

Measurement of the fate of fertilizer ${ }^{15} \mathrm{~N}$ in different treatments of Weirdale loam under field conditions had shown that the nitrificaiton inhibitor (ATC) reduced fertilizer ${ }^{15} \mathrm{~N}$ losses and increased the amount of ${ }^{15} \mathrm{~N}$ remaining in soil at the end of the season (Juma and Paul, 1983). The $\mathrm{NH}_{4} \mathrm{OH}$-treated Weirdale loam contained $147 \mathrm{ng}{ }^{15} \mathrm{~N} \mathrm{~g}^{-1}$ soil while the $\mathrm{NH}_{4} \mathrm{OH}+$ ATC-treated loam contained $352 \mathrm{ng}{ }^{15} \mathrm{~N} \mathrm{~g}^{-1}$ soil. $\mathrm{Cu}-$ mulative net ${ }^{15} \mathrm{~N}$ mineralized in the two treatments of Weirdale loam and the cumulative net $\mathrm{N}$ mineralized in all soils used in this investigation showed curvilinear trends (Table 2).

\begin{tabular}{|c|c|c|c|c|c|c|c|}
\hline \multirow[b]{4}{*}{ Time } & \multicolumn{7}{|c|}{ Cumulative net $\mathrm{N}$ mineralized } \\
\hline & \multicolumn{7}{|c|}{ Soil designation } \\
\hline & \multicolumn{2}{|c|}{ Weirdale loam } & \multicolumn{2}{|c|}{ Indian Head clay } & \multicolumn{3}{|c|}{ Bradwell fine sandy loam } \\
\hline & $\mathrm{NH}, \mathrm{OH}$ & $\mathrm{NH}_{4} \mathrm{OH}+\mathrm{ATC}$ & Rot. R & Rot. C & Wheat (a) & Wheat (b) & Alfalfa \\
\hline weeks & \multicolumn{7}{|c|}{$-\mu \mathrm{g} \mathrm{g}^{-1}$ soil- } \\
\hline 1 & $8.8(3.5) \dagger$ & $13.1(11.4) \dagger$ & 13.9 & 8.4 & 11.2 & - & -. \\
\hline 2 & $15.8(6.3)$ & $19.7(17.7)$ & 19.6 & 14.0 & 20.3 & 15.2 & 9.2 \\
\hline 3 & $31.9(12.5)$ & $29.3(24.8)$ & 26.4 & 19.6 & 27.9 & - & - \\
\hline 4 & $39.3(15.0)$ & - & 35.1 & 26.3 & 33.9 & - & - \\
\hline 5 & - & $39.5(32.7)$ & 41.5 & 32.3 & $\ldots$ & 29.4 & 14.6 \\
\hline 6 & $52.4(20.7)$ & .. & 52.6 & 44.4 & 52.0 & $\ldots$ & -. \\
\hline 7 & .. & $52.7(43.4)$ & 60.0 & 51.5 &.- & .. & .. \\
\hline 8 & $64.8(25.7)$ & .. & -- & $\ldots$ & 59.6 & 33.3 & 20.1 \\
\hline 9 & -. & $70.3(55.9)$ & 73.4 & 64.3 & .. & - & -. \\
\hline 10 & $82.5(32.7)$ & -. & -- & - & 70.5 & - & -- \\
\hline 11 & - & $86.0(65.5)$ & 85.8 & 76.0 & .. & 41.3 & 25.0 \\
\hline 12 & $95.0(37.2)$ & -. & - & - & 81.3 & - & - \\
\hline 13 & - & - & 96.0 & 86.6 & - & - & -- \\
\hline 14 & - & $100.8(74.3)$ & - & - & -- & 46.3 & 28.2 \\
\hline 15 & $106.5(40.9)$ & - & 104.2 & 93.1 & 92.0 & -. & -- \\
\hline 17 & - & $115.5(82.6)$ & .. & - & -- & - & -- \\
\hline 18 & $116.5(44.1)$ & - & -. & -- & 98.0 & -- & -. \\
\hline 19 & - & - & 120.0 & 102.7 & -- & - & - \\
\hline 21 & - & - & - & -. & 102.6 & - & - \\
\hline 22 & -- & - & 123.3 & 111.3 & - & -- & -- \\
\hline 24 & -- & - & -. & - & 107.2 & -- & -- \\
\hline 25 & .. & - & 128.4 & 116.3 & -- & - & -- \\
\hline
\end{tabular}

Table 2-Cumulative net $\mathrm{N}$ mineralized in several Saskatchewan soils.

$\dagger$ Figures in parenthesis are cumulative ${ }^{15} \mathrm{~N}$ mineralized (ng $\mathrm{g}^{-1}$ soil). 
The NLLS method yielded the lowest RMS error compared to linear transformations of the hyperbolic equation used to describe net ${ }^{15} \mathrm{~N}$ mineralization. The parameter estimates obtained by NLLS were not significantly different when the data points for weeks 1 and 2 were excluded from the calculation (Table 3 ). The parameters $\mathrm{N}_{0}^{\mathrm{H}}$ and $T_{c}$ [Eq. 4] estimated by minimizing the residual sum of squares showed that the ${ }^{15} \mathrm{~N}_{0}^{\mathrm{H}}$ of the $\mathrm{NH}_{4} \mathrm{OH}$ treatment was almost one-half of the value obtained for $\mathrm{NH}_{4} \mathrm{OH}+$ ATC treatment while the $T_{c}$ values were similar (Table 3 ). This is consistent with the fact that the atom $\%{ }^{15} \mathrm{~N}$ excess of $\mathrm{N}$ being mineralized and biomass $\mathrm{N}$ (measured from $\mathrm{NH}_{4}^{+}$released during 10-d incubation from fumigated samples) were almost twofold higher ( 0.087 vs. 0.043 ) for the $\mathrm{NH}_{4} \mathrm{OH}+$ ATC compared to $\mathrm{NH}_{4} \mathrm{OH}$-treated soil. The biomass is one of the major sources of $\mathrm{N}$ during the net mineralization phase (Paul and Juma, 1981). The ${ }^{15} \mathrm{~N}_{0}^{\mathrm{H}}$ accounted for 53 to $70 \%$ of ${ }^{15} \mathrm{~N}$ remaining in organic and nonexchangeable $\mathrm{NH}_{4}^{+}$forms. If the ${ }^{15} \mathrm{~N}$ in nonexchangeable fraction was subtracted, then ${ }^{15} \mathrm{~N}_{0}^{\mathrm{H}}$ accounted for $62 \%$ of organic $\mathrm{N}$ remaining in the $\mathrm{NH}_{4} \mathrm{OH}+\mathrm{ATC}$ and $72 \%$ in the $\mathrm{NH}_{4} \mathrm{OH}$ treatment. Smith et al. (1978), using the double reciprocal plot, found ${ }^{15} \mathrm{~N}_{0}^{\mathrm{H}}$ accounted for 21 to $57 \%$ of total ${ }^{15} \mathrm{~N}$ (excluding nitrate) remaining in different treatments of an alfisol and a vertisol. Our results also show that the ${ }^{15} \mathrm{~N}_{0}^{\mathrm{H}}$ did not account for all the ${ }^{15} \mathrm{~N}$ remaining in soil.

The value for ${ }^{15} \mathrm{~N}_{0}^{\mathrm{H}}$ obtained with the double reciprocal plot for the $\mathrm{NH}_{4} \mathrm{OH}$ treatment dropped from 530 to $95 \mathrm{ng} \mathrm{g}^{-1}$, with a corresponding decrease in $T_{c}$ from 152 to 20 weeks, when the data for weeks 1 and
2 were excluded from regression analysis (Table 3). In contrast, the estimates of ${ }^{15} \mathrm{~N}_{0}^{\mathrm{H}}$ and $T_{c}$ increased in the $\mathrm{NH}_{4} \mathrm{OH}+$ ATC treatment when the data for weeks 1 and 2 were not considered in the calculation. The $R^{2}$ values for the transformed variables obtained ranged from 0.961 to 0.990 for the two treatments. The RMS error decreased from 5.1 to $1.3 \mathrm{ng} \mathrm{g}^{-1}$ soil when the data for weeks 1 and 2 were excluded from the calculation (Table 3). The other two transformations of the hyperbolic equation (N vs. $\mathrm{N} / t$ and $t / \mathrm{N}$ vs. $t$ ) yielded ${ }^{15} \mathrm{~N}_{0}^{\mathrm{H}}$ and $T_{c}$ estimates which had a narrow range. The $R^{2}$ obtained with transformed variables were low (significant at $P<0.05$ ) when all data were considered and increased when the initial data points were excluded (Table 3 ). The $\mathrm{N}$ vs. $\mathrm{N} / t$ and $t / \mathrm{N}$ vs. $t$ transformations had much lower values of RMS than the double reciprocal plot (Table 3).

Work in enzyme chemistry has shown that the double reciprocal plot yields straight line regressions but the parameter estimates may be quite different from the other transformations of the hyperbolic equation (Segel, 1975). This is primarily because the double reciprocal plot gives undue emphasis to the initial points. This is the likely cause for the better fit (lower RMS) obtained with our data when the data for weeks 1 and 2 were excluded. Stanford and Smith (1972) used the double reciprocal plot to obtain an initial estimate of $\mathrm{N}_{0}^{F}$ but did not use the amount of $\mathrm{N}$ mineralized in the first four weeks of incubation in regression analysis. Instead, they added the amount of $\mathrm{N}$ mineralized in the 4 weeks to the parameter value estimated from 4- to 30-week incubation. This approach yielded reasonable initial estimates of $\mathrm{N}_{0}$.

Table 3-Estimates of $\mathrm{N}$ mineralization potential $\left({ }^{15} \mathrm{~N}_{0}^{\mathrm{H}}\right)$ and time required for one-half ${ }^{15} \mathrm{~N}_{0}^{\mathrm{H}}$ to mineralize $\left(T_{c}\right)$ as determined by different fitting techniques for two treatments of Weirdale loam.

\begin{tabular}{|c|c|c|c|c|c|}
\hline Equation & $\begin{array}{l}\text { Incubatior } \\
\text { period }\end{array}$ & Predicted ${ }^{15} \mathrm{~N}_{0}^{\mathrm{H}}$ & Predicted $T_{\mathrm{c}}$ & $\begin{array}{c}R^{2} \text { with } \\
\text { transformed variables }\end{array}$ & RMS \\
\hline & weeks & $\mathbf{n g} \mathbf{g}^{-1}$ soil & weeks & & $\mathrm{ng}^{16} \mathrm{Ng}^{-1}$ soil \\
\hline \multicolumn{6}{|c|}{ Weirdale loam- $\mathrm{NH}_{4} \mathrm{OH}$ treatment } \\
\hline $\mathrm{N}=\mathrm{N}_{0}^{\mathrm{H}} \cdot t /\left(T_{c}+t\right) \dagger$ & $\begin{array}{l}0-18 \\
2-18 \\
3-18\end{array}$ & $\begin{array}{r}105 \pm 12 \\
104 \pm 12 \\
99 \pm 10\end{array}$ & $\begin{array}{l}24 \pm 4 \\
23 \pm 4 \\
22 \pm 3\end{array}$ & $\begin{array}{l}- \\
-\end{array}$ & $\begin{array}{l}1.29 \\
1.34 \\
1.17\end{array}$ \\
\hline $1 / \mathrm{N}=1 / \mathrm{N}_{0}^{\mathrm{H}}+T_{c} / \mathrm{N}_{0}^{\mathrm{H}}(1 / t)$ & $\begin{array}{l}0-18 \\
2-18 \\
3-18\end{array}$ & $\begin{array}{r}530 \\
706 \\
95\end{array}$ & $\begin{array}{r}152 \\
204 \\
20\end{array}$ & $\begin{array}{l}0.990 \\
0.961 \\
0.993\end{array}$ & $\begin{array}{l}5.07 \\
5.88 \\
1.25\end{array}$ \\
\hline $\mathrm{N}=\mathrm{N}_{0}^{\mathrm{H}}-T_{c}(\mathrm{~N} / t)$ & $\begin{array}{l}0-18 \\
2-18 \\
3-18\end{array}$ & $\begin{array}{l}93 \pm 11 \\
39 \pm 10 \\
96 \pm 4\end{array}$ & $\begin{array}{l}21 \pm 7 \\
19 \pm 7 \\
21 \pm 3\end{array}$ & $\begin{array}{l}0.498 \\
0.540 \\
0.901\end{array}$ & $\begin{array}{l}2.01 \\
1.93 \\
1.20\end{array}$ \\
\hline$t / \mathbf{N}=T_{c} / \mathbf{N}_{0}^{\mathrm{H}}+1 / \mathbf{N}_{0}^{\mathbf{H}}(t)$ & $\begin{array}{l}0-18 \\
2-18 \\
3-18\end{array}$ & $\begin{array}{l}142 \\
129 \\
101\end{array}$ & $\begin{array}{l}37 \\
32 \\
22\end{array}$ & $\begin{array}{l}0.699 \\
0.727 \\
0.953\end{array}$ & $\begin{array}{l}1.70 \\
1.61 \\
1.18\end{array}$ \\
\hline \multicolumn{6}{|c|}{ Weirdale loam- $\mathrm{NH}_{4} \mathrm{OH}+\mathrm{ATC}$ treatment } \\
\hline $\mathbf{N}=\mathbf{N}_{0}^{\mathrm{H}} \cdot t /\left(T_{c}+t\right) \dagger$ & $\begin{array}{l}0-17 \\
2-17 \\
3-17\end{array}$ & $\begin{array}{l}187 \pm 20 \\
192 \pm 20 \\
199 \pm 22\end{array}$ & $\begin{array}{l}21 \pm 3 \\
22 \pm 3 \\
24 \pm 4\end{array}$ & $\begin{array}{l}- \\
-\end{array}$ & $\begin{array}{l}2.21 \\
2.03 \\
2.04\end{array}$ \\
\hline $1 / \mathbf{N}=1 / \mathbf{N}_{0}^{\mathbf{H}}+T_{\mathrm{c}} / \mathbf{N}_{0}^{\mathbf{H}}(1 / t)$ & $\begin{array}{l}0-17 \\
2-17 \\
3-17\end{array}$ & $\begin{array}{r}97 \\
139 \\
155\end{array}$ & $\begin{array}{r}8 \\
14 \\
17\end{array}$ & $\begin{array}{l}0.981 \\
0.990 \\
0.978\end{array}$ & $\begin{array}{l}8.89 \\
4.18 \\
3.45\end{array}$ \\
\hline $\mathbf{N}=\mathrm{N}_{0}^{\mathrm{H}}-T_{c}(\mathrm{~N} / t)$ & $\begin{array}{l}0-17 \\
2-17 \\
3-17\end{array}$ & $\begin{array}{l}123 \pm 13 \\
154 \pm 10 \\
165 \pm 10\end{array}$ & $\begin{array}{l}11 \pm 2 \\
16 \pm 3 \\
18 \pm 4\end{array}$ & $\begin{array}{l}0.791 \\
0.860 \\
0.822\end{array}$ & $\begin{array}{l}4.85 \\
2.94 \\
2.70\end{array}$ \\
\hline$t / \mathrm{N}=T_{c} / \mathrm{N}_{0}^{\mathrm{H}}+1 / \mathrm{N}_{0}^{\mathrm{H}}(t)$ & $\begin{array}{l}0-17 \\
2-17 \\
3-17\end{array}$ & $\begin{array}{l}155 \\
176 \\
193\end{array}$ & $\begin{array}{l}\mathbf{1 6} \\
20 \\
22\end{array}$ & $\begin{array}{l}0.907 \\
0.932 \\
0.922\end{array}$ & $\begin{array}{l}2.77 \\
2.16 \\
2.06\end{array}$ \\
\hline
\end{tabular}

† This equation was used in the nonlinear least squares method. 
Table 4-Estimates of the parameters of the hyperbolic equation using the NLLS technique to describe the net $\mathrm{N}$ mineralization in several Saskatchewan soils and comparison of experimental with predicted values.

\begin{tabular}{|c|c|c|c|c|c|}
\hline \multirow[b]{2}{*}{ Designation } & \multirow[b]{2}{*}{$\mathbf{N}_{0}^{\mathbf{H}}$} & \multirow[b]{2}{*}{$T_{c}$} & \multirow[b]{2}{*}{ RMS } & \multicolumn{2}{|c|}{$\begin{array}{l}N \text { mineralized } \\
\text { after } 14 \text { weeks }\end{array}$} \\
\hline & & & & $\begin{array}{l}\text { Experi- } \\
\text { mental }\end{array}$ & $\begin{array}{c}\text { Pre- } \\
\text { dicted }\end{array}$ \\
\hline & $\mu \mathrm{g} \mathrm{g}^{-1}$ & weeks & & $\mu \mathrm{g} \mathrm{g}^{-1}$ & \\
\hline \multicolumn{6}{|c|}{ Weirdale loam } \\
\hline $\begin{array}{l}\mathrm{NH}, \mathrm{OH} \\
\mathrm{NH}, \mathrm{OH}+\mathrm{ATC}\end{array}$ & $\begin{array}{l}302 \pm 33 \dagger \\
429 \pm 86\end{array}$ & $\begin{array}{l}27.6 \pm 4.3^{\dagger} \\
45.8 \pm 11.7\end{array}$ & $\begin{array}{l}2.8 \\
3.0\end{array}$ & $\begin{array}{l}103 \\
101\end{array}$ & $\begin{array}{l}103 \\
100\end{array}$ \\
\hline \multicolumn{6}{|c|}{ Indian Head clay } \\
\hline $\begin{array}{l}\text { Rotation C } \\
\text { Rotation R }\end{array}$ & $\begin{array}{l}259 \pm 26 \\
253 \pm 15\end{array}$ & $\begin{array}{l}28.6 \pm 4.4 \\
22.4 \pm 2.2\end{array}$ & $\begin{array}{l}4.0 \\
3.2\end{array}$ & $\begin{array}{r}90 \\
100\end{array}$ & $\begin{array}{l}85 \\
97\end{array}$ \\
\hline \multicolumn{6}{|c|}{ Bradwell fine sandy loam } \\
\hline $\begin{array}{l}\text { Wheat (a) } \\
\text { Wheat (b) } \\
\text { Alfalfa }\end{array}$ & $\begin{array}{r}180 \pm 7 \\
69 \pm 7 \\
51 \pm 7\end{array}$ & $\begin{array}{r}15.5 \pm 1.1 \\
7.3 \pm 1.7 \\
11.4 \pm 3.0\end{array}$ & $\begin{array}{l}2.1 \\
1.9 \\
1.1\end{array}$ & $\begin{array}{l}89 \\
46 \\
28\end{array}$ & $\begin{array}{l}85 \\
45 \\
28\end{array}$ \\
\hline
\end{tabular}

$\dagger$ Parameter values \pm standard error of estimate.

The estimates of the parameters of the hyperbolic model using NLLS technique for Saskatchewan soils (Table 4) showed that both parameters, $\mathrm{N}_{0}$ and $T_{c}$, are important to predict the net $\mathrm{N}$ mineralization. Although the $\mathrm{N}_{0}^{\mathrm{H}}$ values for Rotation $\mathrm{C}$ and Rotation $\mathrm{R}$ are similar, the amount of $\mathrm{N}$ mineralized in Rotation $\mathrm{R}$ was greater and better described by a lower $T_{c}$. In contrast, the amounts of $\mathrm{N}$ mineralized in $\mathrm{NH}_{4} \mathrm{OH}$ and $\mathrm{NH}_{4} \mathrm{OH}+$ ATC soils were similar, but the $\mathrm{N}_{0}$ and $T_{c}$ values were completely different. The Bradwell fine sandy loam designated as wheat (b) and alfalfa had $\mathrm{N}_{0}^{\mathrm{H}}$ values which were $\sim 1 / 3$ of $\mathrm{N}_{0}^{\mathrm{H}}$ of soil designated as wheat (a). These soils had low amounts of organic matter and low $\mathrm{N}$-supplying power because they had been leveled for irrigation purposes.

The NLLS method was used to estimate the parameters of the first order equation used to describe net $\mathrm{N}$ mineralization in labeled and unlabeled soils. The ${ }^{15} \mathrm{~N}_{0}^{\mathrm{F}}$ estimate of the $\mathrm{NH}_{4} \mathrm{OH}$ treatment of Weirdale loam was $64 \mathrm{ng} \mathrm{g}^{-1}$; it was $118 \mathrm{ng}^{15} \mathrm{~N} \mathrm{~g}^{-1}$ for the $\mathrm{NH}_{4} \mathrm{OH}+$ ATC treatment (Table 5). These accounted for $44 \%$ of organic ${ }^{15} \mathrm{~N}$ remaining in $\mathrm{NH}_{4} \mathrm{OH}$ treatment and $30 \%$ for $\mathrm{NH}_{4} \mathrm{OH}+$ ATC treatment. The half life of the ${ }^{15} \mathrm{~N}_{0}^{\mathrm{F}}$ for the two treatments was similar and ranged from 9.7 to 10.5 weeks.

The $\mathrm{N}_{0}^{\mathrm{F}}$ for seven Saskatchewan soils ranged from

Table 5-Estimates of $N$ mineralization potential $\left({ }^{15} N_{0}^{F}\right)$ and net mineralization rate constant $(k)$ for two treatments of Weirdale loam

\begin{tabular}{|c|c|c|c|c|}
\hline $\begin{array}{l}\text { Incubation } \\
\text { period }\end{array}$ & ${ }^{15} \mathrm{~N}_{0}^{\mathrm{F}}$ & $k$ & $T_{1 / 2} \dagger$ & RMS \\
\hline weeks & $\mathbf{n g} \mathbf{g}^{-1}$ soil & weeks $^{-1}$ & weeks & $\mathrm{ng}{ }^{15} \mathrm{~N} \mathrm{~g}^{-1}$ soil \\
\hline \multicolumn{5}{|c|}{$\mathrm{NH}_{4} \mathrm{OH}$ treatment } \\
\hline $\begin{array}{l}0-18 \\
2-18 \\
3-18\end{array}$ & $\begin{array}{l}64 \pm 5 \dagger \\
64 \pm 5 \\
62 \pm 4\end{array}$ & $\begin{array}{l}0.0671 \pm 0.0082 \ddagger \\
0.0678 \pm 0.0086 \\
0.0712 \pm 0.0078\end{array}$ & $\begin{array}{r}10.3 \\
10.2 \\
9.7\end{array}$ & $\begin{array}{l}1.2 \\
1.2 \\
1.1\end{array}$ \\
\hline \multicolumn{5}{|c|}{$\mathrm{NH}_{4} \mathrm{OH}+$ ATC treatment } \\
\hline $\begin{array}{l}0-17 \\
2-17 \\
3-17\end{array}$ & $\begin{array}{l}118 \pm 10 \ddagger \\
120 \pm 10 \\
123 \pm 11\end{array}$ & $\begin{array}{l}0.0712 \pm 0.0096 \ddagger \\
0.0690 \pm 0.0087 \\
0.0662 \pm 0.0087\end{array}$ & $\begin{array}{r}9.7 \\
10.0 \\
10.5\end{array}$ & $\begin{array}{l}2.3 \\
2.1 \\
2.0\end{array}$ \\
\hline
\end{tabular}

$+T_{1 / 2}=0.693 / k$

$\ddagger$ Parameter value \pm standard error of estimate.
35 to $255 \mu \mathrm{g} \mathrm{N} \mathrm{g}^{-1}$ soil while the $k$ ranged from 0.036 to 0.164 weeks $^{-1}$ at $28^{\circ} \mathrm{C}$ (Table 6). Both equations accurately predicted the amount of $\mathrm{N}$ mineralized after 14 weeks incubation. The RMS values for the two models were similar for each soil, thus either model appears to adequately describe the kinetics of net $\mathrm{N}$ mineralization.

The use of first order equation to describe net $\mathrm{N}$ mineralization assumes that the rate of $\mathrm{N}$ mineralization is proportional to the size of the mineralizable pool $(d \mathrm{~N} / d t=-k \mathrm{~N})$. A narrow range of $k$ values (0.054-0.058 weeks ${ }^{-1}$ at $35^{\circ} \mathrm{C}$ and $34 \mathrm{kPa}$ soil pore moisture tension) have been reported for a wide variety of soils (Stanford and Smith, 1972; Oyanedel and Rodriguez, 1977) using the iterative calculation procedure of Stanford and Smith (1972). However, the parameter estimates are very much dependent on the method of fitting. It has been shown that the NLLS method yields less ambiguous estimates of the parameters (Mary and Remy, 1979; Talpaz et al., 1981). The values of $k$ for Saskatchewan soils used in this investigation ranged from 0.036 to 0.164 weeks $^{-1}$ at $28^{\circ} \mathrm{C}$. Mary and Remy (1979) have reported values of 0.028 to 0.040 weeks $^{-1}$ at $35^{\circ} \mathrm{C}$ and even lower values for longer incubations (Mary and Remy, unpublished data). These results support neither the universality of a rate constant $k$ nor the suggestion that "the forms of organic $\mathrm{N}$ contributing to $\mathrm{N}_{0}$ are similar for most of the soils" (Stanford and Smith, 1972).

The $\mathrm{N}_{0}$ values obtained by NLLS fitting of the hyperbolic, exponential, or double exponential (Molina et al., 1980) equations are mathematically defined quantities obtained from the kinetic analysis of the net $\mathrm{N}$ mineralization. The existence of $\mathrm{N}_{0}$ as a homogeneous, discrete organic $\mathrm{N}$ pool in soil is unlikely. Numerous studies on the internal cycling of $\mathrm{N}$ have shown that $\mathrm{N}$ in soil is present in various pools or fractions which undergo mineralization at different rates. Tracer studies have shown that the recently immobilized $\mathrm{N}$ is transferred through different soil fractions such as the humic and fulvic acids (Broadbent, 1968; McGill et al., 1975; Sochtig and Salfeld, 1977) and fractions obtained with acid hydrolysis (Stewart

\begin{tabular}{|c|c|c|c|c|c|c|}
\hline \multirow[b]{2}{*}{ Designation } & \multirow[b]{2}{*}{$\mathbf{N}_{0}^{\mathrm{F}}$} & \multirow[b]{2}{*}{$k$} & \multirow[b]{2}{*}{$T_{1 / 2}$} & \multirow[b]{2}{*}{ RMS } & \multicolumn{2}{|c|}{$\begin{array}{l}N \text { mineralized } \\
\text { after } 14 \text { weeks }\end{array}$} \\
\hline & & & & & $\begin{array}{l}\text { Experi- } \\
\text { mental }\end{array}$ & $\begin{array}{l}\text { Pre- } \\
\text { dicted }\end{array}$ \\
\hline & $\begin{array}{c}\mu \mathrm{g} \mathrm{N} \mathrm{g}^{-1} \\
\text { soil }\end{array}$ & week $^{-1}$ & weeks & & $\mathbf{N ~ g ~}^{-1}$ soil & 1 \\
\hline \multicolumn{7}{|c|}{ Weirdale loam } \\
\hline $\begin{array}{l}\mathrm{NH}_{4} \mathrm{OH} \\
\mathrm{NH}_{6} \mathrm{OH}+\mathrm{ATC}\end{array}$ & $\begin{array}{l}182 \pm 15 \\
255 \pm 49\end{array}$ & $\begin{array}{r}0.059 \pm 0.007 \\
0.036 \pm 0.008\end{array}$ & $\begin{array}{l}11.7 \\
19.0\end{array}$ & $\begin{array}{l}2.7 \\
3.1\end{array}$ & $\begin{array}{l}103 \\
102\end{array}$ & $\begin{array}{l}101 \\
101\end{array}$ \\
\hline \multicolumn{7}{|c|}{ Indian Head clay } \\
\hline $\begin{array}{l}\text { Rotation C } \\
\text { Rotation R }\end{array}$ & $\begin{array}{l}160 \pm 11 \\
163 \pm 6\end{array}$ & $\begin{array}{l}0.055 \pm 0.006 \\
0.066 \pm 0.004\end{array}$ & $\begin{array}{l}12.6 \\
10.5\end{array}$ & $\begin{array}{l}3.6 \\
2.6\end{array}$ & $\begin{array}{r}90 \\
100\end{array}$ & $\begin{array}{l}86 \\
98\end{array}$ \\
\hline \multicolumn{7}{|c|}{ Bradwell fine sandy loam } \\
\hline $\begin{array}{l}\text { Wheat (a) } \\
\text { Wheat (b) } \\
\text { Alfalfa }\end{array}$ & $\begin{array}{r}123 \pm 2 \\
50 \pm 4 \\
35 \pm 4\end{array}$ & $\begin{array}{l}0.087 \pm 0.003 \\
0.164 \pm 0.032 \\
0.116 \pm 0.027\end{array}$ & $\begin{array}{l}8.0 \\
4.2 \\
6.0\end{array}$ & $\begin{array}{l}1.6 \\
2.3 \\
1.3\end{array}$ & $\begin{array}{l}89 \\
46 \\
28\end{array}$ & $\begin{array}{l}87 \\
45 \\
28\end{array}$ \\
\hline
\end{tabular}

† Parameter value \pm standard error of estimate. 
et al., 1963; Ladd and Paul, 1973). $\mathrm{N}$ is also transferred between different particle size fractions (Chichester, 1970; Ladd et al., 1977).

From a kinetic point of view, the microbial biomass as measured by the chloroform fumigation technique and the nonbiomass active $\mathrm{N}$ undergo mineralization more rapidly (Paul and Juma, 1981) compared to the bulk of soil organic matter, which is either chemically recalcitrant or physically protected (Jenkinson, 1971; Martel and Paul, 1974). A realistic model of $\mathrm{N}$ cycling in soil should at least consider three to four compartments. Juma and Paul (1981) have shown that biomass, nonbiomass active $\mathrm{N}$, and stabilized $\mathrm{N}$ contributed almost equally to the $\mathrm{N}$ mineralized during a 12 week incubation of Weirdale loam soil. Their calculations showed that old $N$ contributed $<1 \%$ of the cumulative $\mathrm{N}$ mineralized over 12 weeks. The mathematically defined potentially mineralizable $\mathrm{N}\left(\mathrm{N}_{0}^{\mathrm{H}}\right.$ or $N_{0}^{F}$ ) crosses all these organic $N$ pools in soil and does not correspond only to organic $\mathrm{N}$ pools which cycle rapidly. This is supported by the fact that ${ }^{15} \mathrm{~N}_{0}^{\mathrm{H}}$ or ${ }^{15} \mathrm{~N}_{0}^{\mathrm{F}}$ did not account for all the ${ }^{15} \mathrm{~N}$ that was present in organic and nonexchangeable $\mathrm{NH}_{4}^{+}$forms.

\section{CONCLUSIONS}

The hyperbolic equation can be used to describe the net $\mathrm{N}$ mineralization in soil, although to date it has only been used to obtain the first approximation of $\mathrm{N}_{0}^{\mathrm{F}}$ for many soils. The double reciprocal plot gave undue weight to the initial data points and yielded $\mathrm{N}_{0}^{\mathrm{H}}$ and $T_{c}$ estimates which were markedly different from those obtained with other transformations of the hyperbolic equation or with the NLLS method when all the data were considered. The parameter estimates of the hyperbolic equation, $\mathrm{N}_{0}^{\mathrm{H}}$ and $T_{c}$, were best estimated with NLLS regression method. The $\mathrm{N}_{0}^{\mathrm{H}}$ values for the Saskatchewan soils ranged from 51 to $429 \mu \mathrm{g}$ $\mathrm{N} \mathrm{g}^{-1}$ soil while the $T_{c}$ values ranged from 7.3 to 45.8 weeks. The $\mathrm{N}_{0}^{\mathrm{F}}$ and $k$ estimates of the first order equation obtained by NLLS method ranged from 35 to 255 $\mu \mathrm{g} \mathrm{N} \mathrm{g}{ }^{-1}$ soil and 0.036 to 0.164 weeks $^{-1}$, respectively.

The ${ }^{15} \mathrm{~N}_{0}^{\mathrm{H}}$ and ${ }^{15} \mathrm{~N}_{0}^{\mathrm{F}}$ accounted for 67 and $42 \%$ of the organic ${ }^{15} \mathrm{~N}$ remaining in two treatments of the Weirdale soil, respectively. Both equations accurately predicted the amount of $\mathrm{N}$ mineralized during 14-week incubation although the parameter estimates obtained were very different and depended upon the equation used.

\section{ACKNOWLEDGMENTS}

We thank: Western Co-operative Fertilizers, Canadian Wheat Board, Natural Sciences and Engineering Research Council, the Killam Memorial Trust and Farming for the Future for financial support; $\mathrm{N}$. Binder for ${ }^{15} \mathrm{~N}$ mass spectrometer analyses; C. Nguyen for helping in statistical analysis; Agriculture Canada, Indian Head, for permission to sample their long term rotations; and Dr. W.B. McGill for his advice and support.

\section{REFERENCES}

1. Bremner, J.M. 1965. Inorganic forms of nitrogen. In C.A. Black et al. (ed.) Methods of soil analysis, part 2. Agronomy 9:11791237. Am. Soc. of Agron., Madison, WI.
2. Broadbent, F.E. 1968. Nitrogen immobilization in relation to $\mathrm{N}$-containing fractions of soil organic matter. pp. 131-142. In Isotopes and radiation in soil organic matter studies. IAEA, Vienna.

3. Campbell, C.A., R.J.K. Myers, and K.L. Weier. 1981. Nitrogen mineralization potentials, decomposition rates and their relationship to temperature for five Queensland soils. Aust. J. Soil Res. 19:323-332.

4. Chichester, F.W. 1970. Transformation of fertilizer nitrogen in soil. II. Total and ${ }^{15} \mathrm{~N}$-labeled nitrogen of soil organomineral sedimentation fractions. Plant Soil 33:437-456.

5. Herlihy, M. 1979. Nitrogen mineralization in soils of varying texture, moisture and organic matter. I. Potential and experimental values in fallow soils. Plant Soil 53:255-267.

6. Jenkinson, D.S. 1971. Radiocarbon dating of soil organic matter. Rep. Rothamsted Exp. Stn. for 1970, pt. 1:74-75.

7. Juma, N.G., and E.A. Paul. 1981. Use of tracer and computer simulation techniques to assess mineralization and immobilization of soil nitrogen. p. 145-154. In M.J. Frissel and J.A. van Veen (ed.) Simulation of nitrogen behavior of soil plant systems. Pudoc, Wageningen, The Netherlands.

8. Juma, N.G., and E.A. Paul. 1983. Effect of a nitrification inhibitor on $\mathrm{N}$ immobilization and release of ${ }^{\text {is }} \mathrm{N}$ from nonexchangeable ammonium and microbial biomass. Can. J. Soil Sci. 63:167-175.

9. Ladd, J.N., J.W. Parsons, and M. Amato. 1977. Studies in nitrogen immobilization and mineralization in calcareous soils. II. Mineralization of immobilized nitrogen from soil fractions of different particle size and density. Soil Biol. Biochem. 9:319325.

10. Ladd, J.N., and E.A. Paul. 1973. Changes in enzymic activity and distribution of acid soluble, amino acid-nitrogen in soil during nitrogen immobilization and mineralization. Soil Biol. Biochem. 5:825-840.

11. Martel, Y.A., and E.A. Paul. 1974. The use of radiocarbon dating of organic matter in the study of soil genesis. Soil Sci. Soc. Am. Proc. 38:501-506.

12. Mary, B., and J.C. Remy. 1979. Essai d'appréciation de la capacité de minéralisation de l'azote des sols de grande culture. I. Signification des cinétiques de minéralisation de la matière organique humifiée. Ann. Agron. 30:513-527.

13. McGill, W.B., J.A. Shields, and E.A. Paul. 1975. Relation between carbon and nitrogen turnover in soil organic fractions of microbial origin. Soil Biol. Biochem. 7:57-63.

14. Molina, J.A.E., C.E. Clapp, and W.E. Larson. 1980. Potentially mineralizable nitrogen in soil: The simple exponential model does not apply for the first 12 weeks of incubation. Soil Sci. Soc. Am. J. 44:442-443.

15. Oyanedel, C., and J. Rodriguez. 1977. Estimation of $\mathrm{N}$ mineralization in soils. Cienc. Invest. Agraria 4:33-44.

16. Paul, E.A., and N.G. Juma. 1981. Mineralization and immobilization of nitrogen by microorganisms. In F.E. Clark and T. Rosswall (ed.) Terrestrial nitrogen cycles. Ecol. Bull. (Stockholm) 33:179-195.

17. Ralston, Mary. 1983. Derivative-free nonlinear regression. p. 305-314. In W.J. Dixon (ed.) BMDP statistical software. Univ. of California Press, Berkeley.

18. Segel, I.H. 1975. Enzyme kinetics: behavior and analysis of rapid equilibrium and steady-state enzyme systems. John Wiley \& Sons, New York

19. Sinha, M.K., D.P. Sinha, and H. Sinha. 1977. Organic matter transformations in soils. V. Kinetics of carbon and nitrogen mineralization in soils amended with different organic materials. Plant Soil 46:579-590.

20. Smith, J.L., R.R. Schnabel, B.L. McNeal, and G.S. Campbell. 1980. Potential errors in the first-order model for estimating soil nitrogen mineralization potentials. Soil Sci. Am. J. 44:9961000.

21. Smith, S.J., F.W. Chichester, and D.E. Kissel. 1978. Residual forms of fertilizer nitrogen in field soils. Soil Sci. 125:165-169.

22. Sochtig, $H$,, and J. Salfeld. 1977. Dynamics of organic forms of nitrogen in the nitrogen cycle of soil. p. 285-295. In Soil organic matter studies, Vol. 1. IAEA, Vienna.

22. Stanford, G., and S.J. Smith. 1972. Nitrogen mineralization potentials of soils. Soil Sci. Soc. Am. Proc. 36:465-472.

23. Stewart, B.A., L.K. Porter, and D.D. Johnson. 1963. Immobilization and mineralization of nitrogen in several organic fractions of soils. Soil Sci. Soc. Am. Proc. 27:302-304.

24. Talpaz, H., P. Fine, and B. Bar-Yosef. 1981. On the estimation of N-mineralization parameters from incubation experiments. Soil Sci. Soc. Am. J. 45:993-996.

25. Towill, W. 1980. Long term rotation. p. 46-54. Proc. Soils and Crops Workshop, Saskatoon. 